\title{
Lessons learned from primary school students with photonics learning-by- playing approach
}

\author{
Suwannee Phoojaruenchanachai, Sarun \\ Sumriddetchkajorn, Sataporn Chanhorm
}

Suwannee Phoojaruenchanachai, Sarun Sumriddetchkajorn, Sataporn Chanhorm, "Lessons learned from primary school students with photonics learning-by-playing approach," Proc. SPIE 9666, 11th Education and Training in Optics and Photonics Conference, 966602 (5 June 2009); doi: $10.1117 / 12.2207763$

SPIE Event: Eleventh International Topical Meeting on Education and Training in Optics and Photonics, 2009, St. Asaph, United Kingdom 


\title{
Lessons Learned from Primary School Students with Photonics Learning-by-Playing Approach
}

\author{
Suwannee Phoojaruenchanachai*, Sarun Sumriddetchkajorn, and Sataporn Chanhorm \\ Photonics Technology Laboratory (PTL), \\ National Electronics and Computer Technology Center (NECTEC) \\ National Science and Technology Development Agency (NSTDA) \\ 112 Thailand Science Park, Phahonyothin Rd., Klong 1, \\ Klong Luang, Pathumthani 12120, THAILAND \\ Phone: (66-2) 564-6900 ext. 2106, Fax: (66-2) 564-6774
}

\begin{abstract}
We encourage primary school students in the grades 4-6 to challenge themselves on exploring light in everyday life. At the beginning, we bring in the critical-thinking approach where we use open-ended questions in applications of photonics around them. Later on, we engage them to our photonics lessons via our "Long Len" photonics kit. With our educational kit, we observe that most students in 21 schools from different parts of Thailand are amazed about photonics. They try to play with our kit in their ways, enjoy learning with their friends, and give us back many interesting questions. Based on their evaluations on our approach, $90-98 \%$ of them understand more about topics they already know. They also gain new knowledge and can see how it is applied to everyday life. The remaining percentage relates to students who are shy to interact with us.
\end{abstract}

\section{KEYWORDS}

Photonics playing, Primary learning, Learning-by-playing, Inquiry-Based Process, Critical thinking, Photonics educational kit, Hand-on learning, Optics suitcase.

\section{INTRODUCTION}

Science and Technology (S\&T) has become one of the crucial factors for the development and sustainability of all countries. Today, most countries around the world have focused in building knowledge societies with qualified workforces through science learning and thinking processes ${ }^{1}$. For optics and photonics $(\mathrm{OP})$, it is a fascinating subject for science learning because it inherently composes of art and science at the same time and it surrounds us in our everyday activities. With this awareness, several international and local organizations have offered optics programs, ideas, and processes in teaching optics suitable for primary and secondary school students. They also promote the use of elementary optics in daily life in the development of physical thinking for primary school students ${ }^{2}$. A variety of innovative ideas and methods in teaching optics has also been proposed for teachers ${ }^{3-9}$. Apart from the ideas for teaching OP, many educational kits have been developed as hand-on demonstration tools ${ }^{10-20}$.

*E-mail: suwannee.phoojaruenchanachai@nectec.or.th

Eleventh International Topical Meeting on Education and Training in Optics and

Photonics, edited by K. Alan Shore, Deb Kane, Proc. of SPIE Vol. 9666, 966602

(C) 2009 SPIE, OSA, IEEE, ICO · doi: 10.1117/12.2207763 


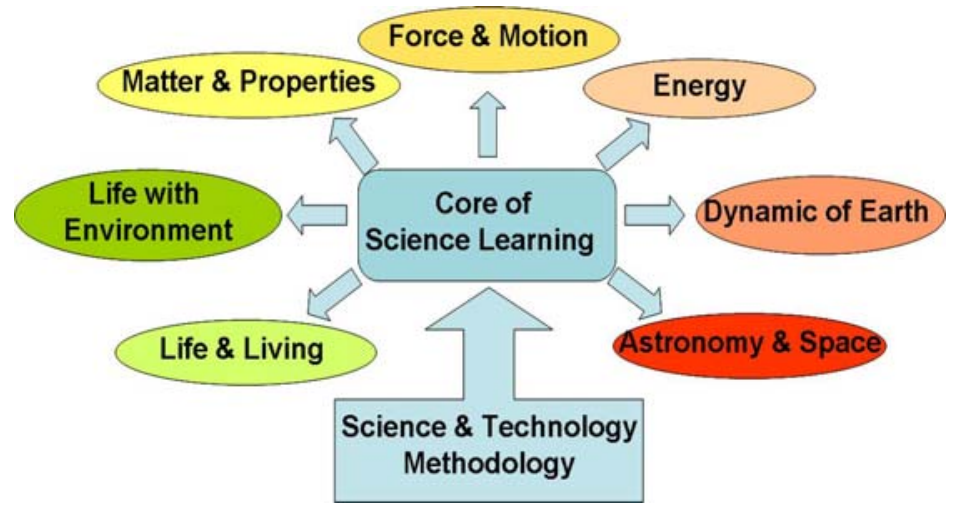

Figure 1. Core theme of science learning in Thailand.

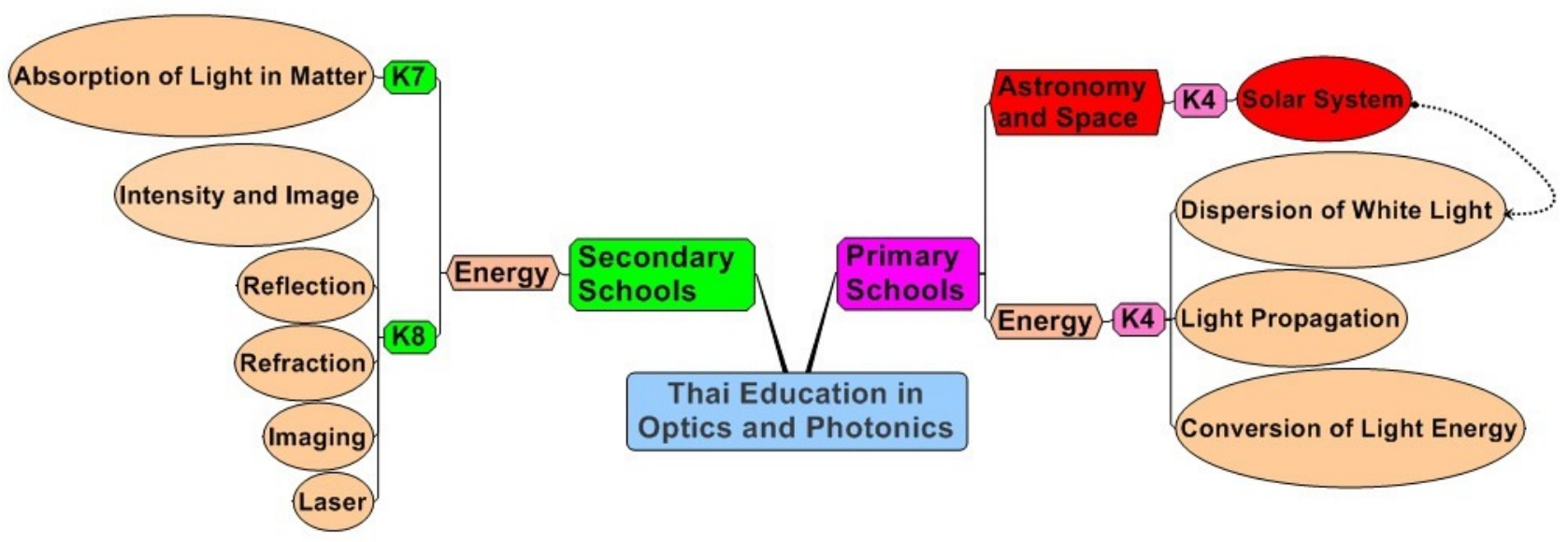

Figure 2. Learning topics in OP for primary and secondary levels.

For Thailand, the core theme ${ }^{21}$ of S\&T learning has been recently established where the S\&T learning process ${ }^{22}$ is applied as shown in Figure 1. With this core theme, teachers or instructors can arrange the proper courses followed the core curriculum and related them to the students and local communities. From those seven areas of science learning, OP is contained in the energy and astronomy sections. They cover basic properties of light such as laws of reflection and refraction, absorption, energy conversion, propagation behaviors of different light sources, and dispersion of white light (see Figure 2). However, as OP is not clearly emphasized in the course, it comes to primary school students as a new technical word that sometimes steers them stay away from learning with it. In addition, there is a discontinuity in learning OP in that they will learn more about it 3-4 years after finishing the K4 level. Additionally, lack of simple educational kits, inefficiency in demonstration, and unskilled science teachers are three key limiting factors that prevent students in primary and secondary schools to pay their attention to science and OP in their future study. With these issues in mind, we bring in our learning-by-playing approach to teach and motivate students in primary schools $^{23}$. We also develop the inquiry-based ${ }^{24}$ with critical thinking process and combine it with child aspect consideration. This paper shows our assessment and lessons learned from 21 schools in different parts of Thailand. 


\section{OUR PEDAGOGICAL KEY APPROACH}

Realizing that primary school students are playful by nature, we utilize this attribute into our approach so that they enjoy learning our activity. In order to assist them envisage the basic OP and its applications in everyday life, a combination of the inquiry-based with critical thinking process and the learningby-playing approach is our key approach to leverage the OP education in primary schools. We arrange the topics in accordance with fundamental optics and applications that can easily be observed around students. All topics in our approach are shown in Table 1. In addition, we bring into the field optical devices and components that the students have seen or used them before but they do not realize the principles behind. For example, an optical fingerprint scanner is used for their exploration of law of refraction and total internal reflection phenomenon. A multicoated eyeglasses is used to guide them to the optical interference. The use of a CD or a DVD helps us to easily demonstrate the diffraction of white light and to investigate the spectrum of laser and other light sources.

Table 1. OP learning topics in our approach.

\begin{tabular}{|c|c|c|}
\hline Core Contents & Topics & Expected Learning \\
\hline \multirow[t]{5}{*}{ White Light Dispersion } & - What is White Light? & - Properties of white light \\
\hline & - Your Own Rainbow & - Natural refraction in dispersion of white light \\
\hline & - Color Filter & - Simple method to filter color light \\
\hline & - Colorful CD & - Dispersion by CD diffraction \\
\hline & - Interference Rainbow & - Dispersion by interference \\
\hline \multirow[t]{3}{*}{ Light Intensity and Imaging } & - Eye & - Light intensity effect to the human eye \\
\hline & - How to see the image & - Imaging on human eye \\
\hline & - Motion pictures & - Imaging of motion pictures \\
\hline \multirow[t]{3}{*}{ Reflection and Color } & - Reflection angle & - Law of reflection \\
\hline & - Thousand faces & - Multiple reflection \\
\hline & - Color reflection & - Absorption and reflection of light \\
\hline \multirow[t]{3}{*}{ Refraction } & - Light deviation & - Snell's law and total internal reflection \\
\hline & - Invisible glass rod & - An application of refraction \\
\hline & - Virtual image & - Virtual image from refraction \\
\hline \multirow[t]{2}{*}{ Energy Conversion } & - Power of light & - Potential of light \\
\hline & - Solar energy & - Light conversion in electrical energy \\
\hline
\end{tabular}




\section{1 "Long Len" Photonics Kit ${ }^{23}$}

An educational kit is a vital tool in our learning-by-playing approach. Previously we developed our educational photonics kit suitable for practical teaching in both primary and secondary levels. Its name is "Long Len" which in Thai language means "Just plays with it". The kit is able to demonstrate six main contents in OP as shown in Figure 3.

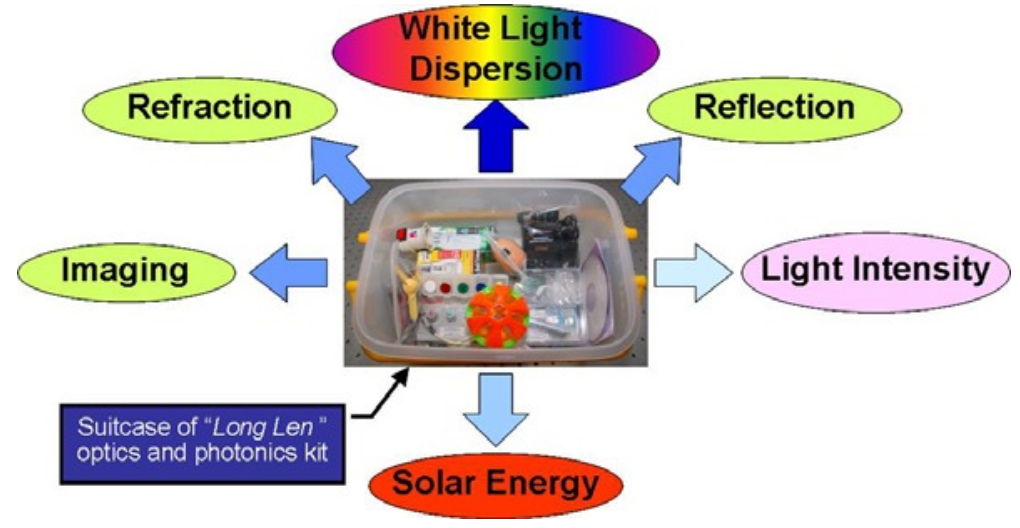

Figure 3. Our Long Len kit and its educational topics.

Components in our educational kit consist of four main parts: optics, electronics, accessories, and manual written in Thai language ${ }^{25}$. Even its plastic suitcase can also be used as a component during some demonstrations. Some parts can be used in several topics. In addition, they can be used for topics that are not related to OP depending on adaptability of teachers or instructors. Our instruction in the manual is designed to guide them along the main topics of OP. Examples of components and demonstrations are shown in Figure 4.
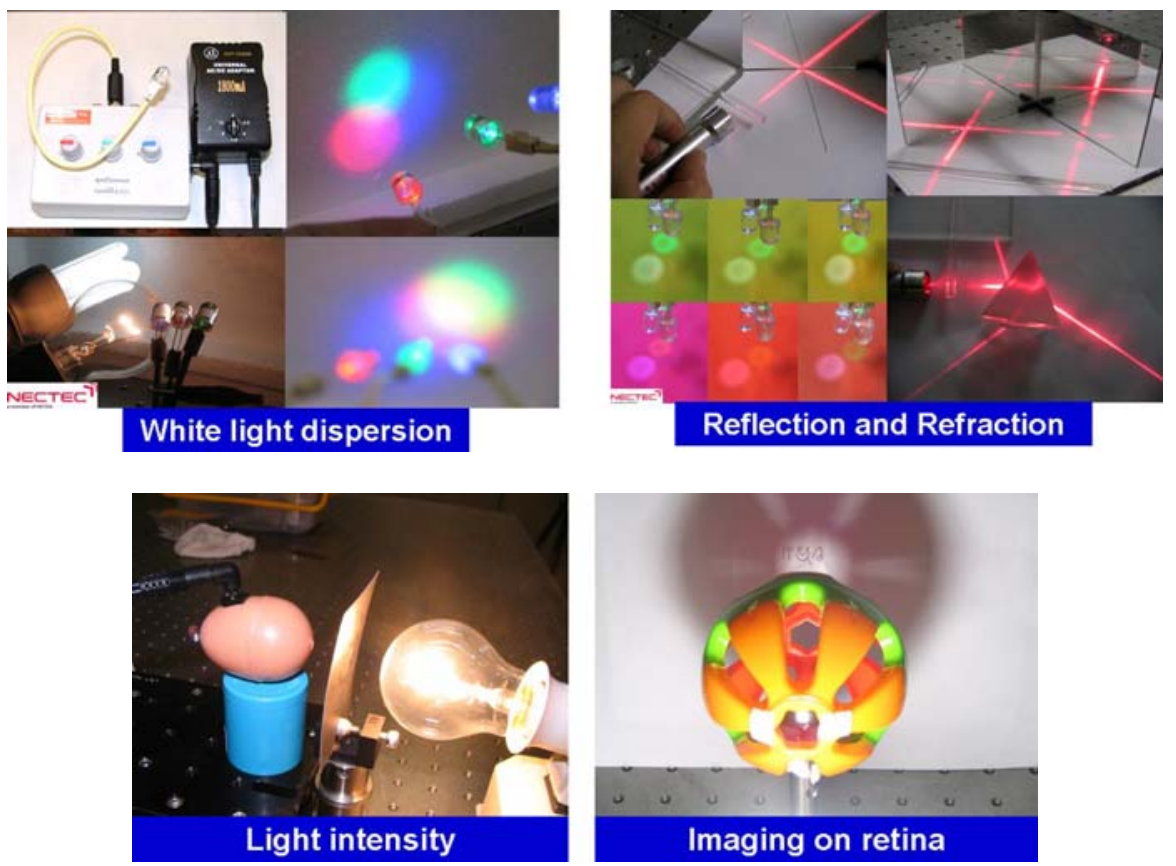

Figure 4. Examples of our demonstrations using our Long Len kit. 


\subsection{Learning-by-playing Approach}

Procedure diagram of our learning-by-playing approach is called 5E's and it is shown in Figure 5.

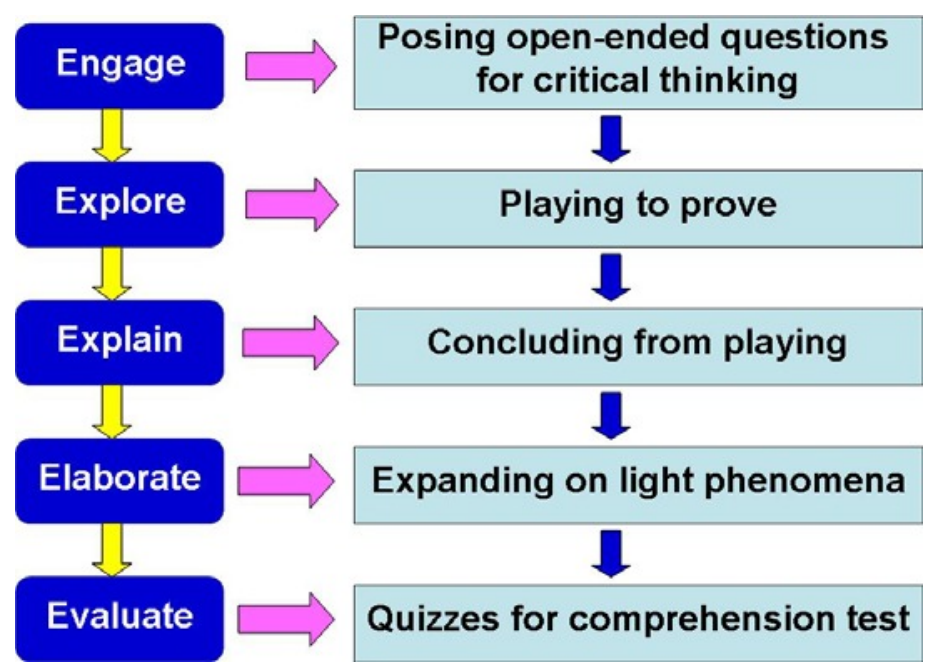

Figure 5. Our 5E-Learning process.

\section{Step 1: Posing Question}

This step is significant to initially inspire primary school students, and therefore the first question to engage them should be simple and it should be related to OP around them. If most students in the class can answer the question, we then encourage them in the following open-ended question in order to bring them into our critical thinking process. Examples of our open-ended questions are shown in Table 2.

Table 2. Examples of questions.

\begin{tabular}{|c|c|}
\hline Core Contents & Questions in Critical Thinking \\
\hline \multirow[t]{4}{*}{ White Light Dispersion } & -What is the difference among bulb, fluorescent, and laser? \\
\hline & - What is white light? \\
\hline & - How is white light dispersion? \\
\hline & -What is the nature phenomenon about white light dispersion? \\
\hline \multirow[t]{3}{*}{ Light Intensity and Imaging } & - What is the imaging on our retina? \\
\hline & $\begin{array}{l}\text { - What is the difference imaging obtained from our eyes and the } \\
\text { camera? }\end{array}$ \\
\hline & - How does the light intensity affect our eye cells? \\
\hline
\end{tabular}




\begin{tabular}{|l|l|}
\hline \multicolumn{1}{|c|}{ Core Contents } & \multicolumn{1}{c|}{ Questions in Critical Thinking } \\
\hline \multirow{3}{*}{ Reflection and Color } & - What is the law of reflection? \\
\cline { 2 - 2 } & - What is the benefit of reflection in everyday life? \\
\cline { 2 - 2 } & $\begin{array}{l}\text { - What is the color reflected from the red object under the green light } \\
\text { source? }\end{array}$ \\
\hline \multirow{2}{*}{ Refraction } & - What is the law of refraction? \\
\cline { 2 - 2 } & - How is the rainbow happening? \\
\hline \multirow{2}{*}{ Energy Conversion } & - Why do you sense hot when touching the bulb or under the sun? \\
\cline { 2 - 2 } & - How can we use the solar energy in everyday life? \\
\hline
\end{tabular}

\section{Step 2: Playing}

In this step, we challenge the students to explore or prove the discussion or solution from our questions in the step 1. We give them all needed components from our Long Len kit that are related to the topics. Prior to playing, we have to introduce students the safety rule concerning using a laser pointer, a light emitting diode (LED) regulator, a light detector, an electrical light bulb, and other electronics equipments. The students subsequently involve in hand-on playing in order for them to explore their critical thinking. At this stage, we are now their assistant. Close observation is also vital to conduct and guide the students before they get confused.

\section{Step 3: Concluding}

This step is to assist the students to analyze what and how they learn from the above step in order to gain the asset of OP knowledge and scientific skill. We lead the students gradually to explain what they have learned during their playing. We also bring them into the critical thinking process again. The students have to conclude points of learning and knowledge gained during the above steps.

\section{Step 4: Expanding}

This step needs students to be able to expand their knowledge to things around them. We can pick up a phenomenon of light to start with. Moreover, if we observe any application of optics or photonics in the class, we use it as a problem for the students to find out the explanation.

\section{Step 5: Quiz}

We end up our approach with quizzes. This step is to evaluate the understanding of the individual student. We ask each student to review his or her thinking and knowledge. Since our approach is informal and no point affects students, we have to make this step more exciting in order to get their cooperation. This can be done by giving them some souvenirs if they can answer our questions correctly.

\section{EVALUATIONS AND LESSONS LEARNED}

We visit 21 primary schools in every part of Thailand. In particular, we focus on the schools in the rural area in Payao, Ratchaburi, Ubolratchathani, Nakornsridhamarach, and Srisakes provinces. There are 1018 students covering 96 in the grade four, 340 in the grade five, and 582 in the grade six. It can be seen that $57.2 \%$ of students is in the grade six because they already learned some basic optics and we anticipate them to gain some benefits so that they can more or less plan their future study. Due to our limited 2-3 hours of demonstrations, we separate students in each school into two groups. The first group is focused on white light dispersion, imaging light intensity, and color reflection. The other group learns more about reflection, refraction, and energy conversion. 


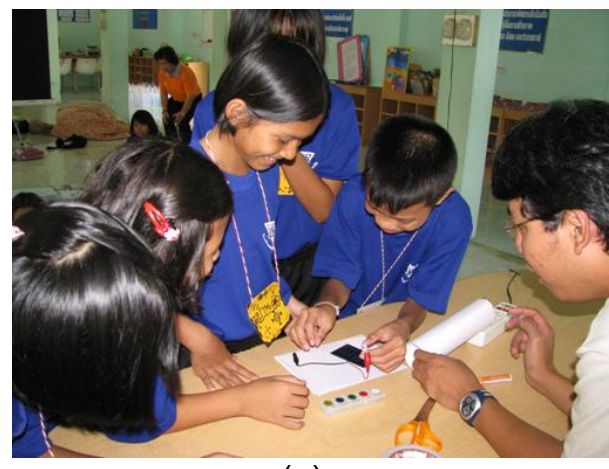

(a)

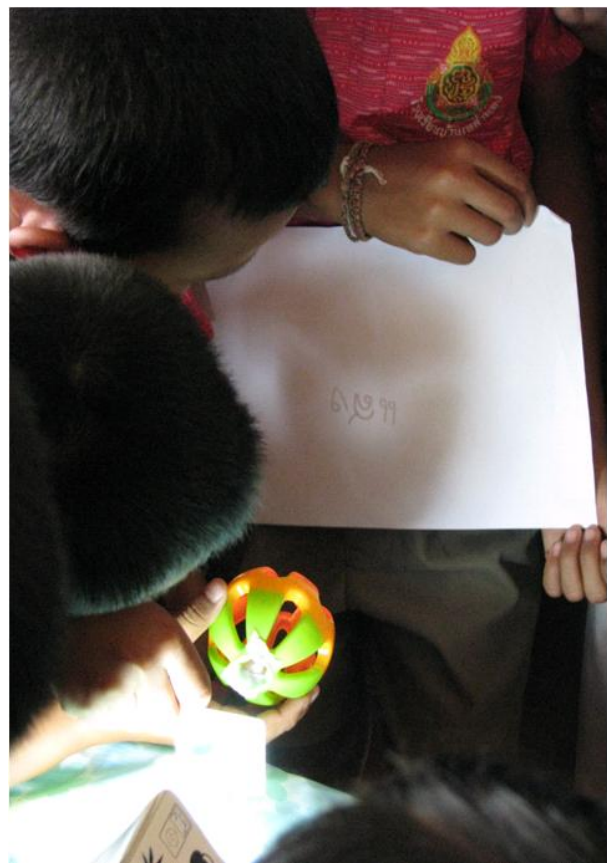

(c)

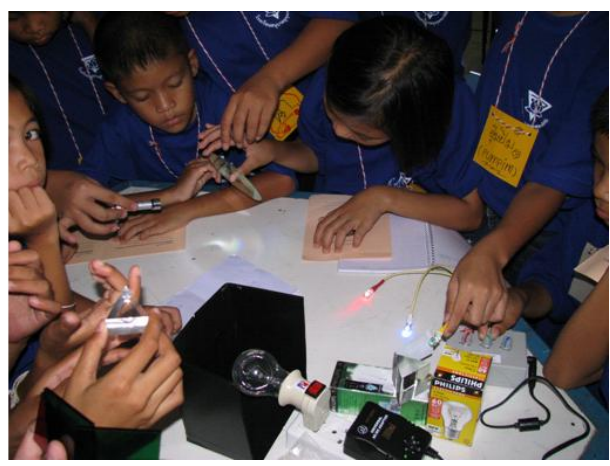

(b)
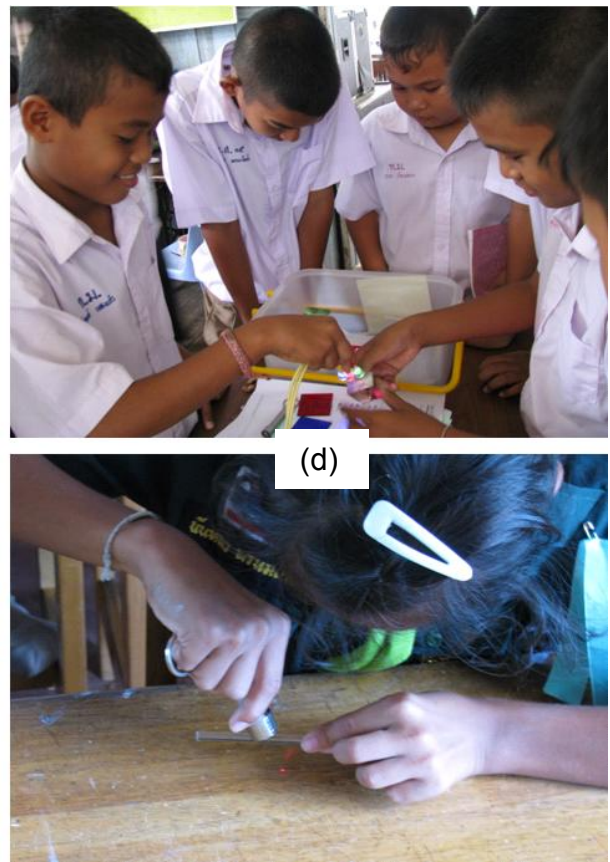

(e)

Figure 6. Snapshots of student activities for (a) energy conversion with the use of a solar cell, (b) white light dispersion with LEDs and a prism, (c) imaging using a plastic ball and a convex lens, (d) color dispersion, and (e) an application of refraction by combining a laser pointer with a cylindrical lens to generate a line of light.

\subsection{Evaluations}

To examine our approach, we end our demonstration with the student evaluation. Our evaluation form has two parts. The first part contains choice assessment while the latter part is for open-minded outlook. For the first part of the evaluation, students mark their desired choice in each topic. Analysis of all evaluation data in this case is shown in Table 3. 
Table 3. Evaluation results from primary school students.

\begin{tabular}{|l|c|c|c|}
\hline \multicolumn{1}{|c|}{ Topics } & Joy and Gain & Norm & Boredom \\
\hline White Light Dispersion & $99.26 \%$ & $0.18 \%$ & $0.18 \%$ \\
\hline Imaging & $98.16 \%$ & $0.74 \%$ & $0.74 \%$ \\
\hline Reflection & $99.25 \%$ & $0.19 \%$ & $0.37 \%$ \\
\hline Color Reflection & $97.61 \%$ & $0.74 \%$ & $0.92 \%$ \\
\hline Refraction & $98.69 \%$ & $0.19 \%$ & $0.00 \%$ \\
\hline Energy Conversion & $99.44 \%$ & $0.00 \%$ & $0.00 \%$ \\
\hline
\end{tabular}

Table 3 indicates that our learning-by-playing approach with critical-thinking process helps students gain more knowledge about OP with fun. In this high evaluation, we also find that some of them knew some topics but they understood more. Less than one percent of students consider all topics excluding energy conversion are normal. The remaining percentage of students regards our approach boring because they gained nothing in particular to the color absorption and the imaging.

We intensely look into the percent of students in the boredom section in order to find out what are the motives behind their evaluations. We believe that communication skill of each instructor, personality of both the instructor and the student, and misconception of students play important roles. We also find that a few students in this group are in the schools located at the frontier and have weak communication in Thai language. Some students need specific teaching style. Those two student types are shy to encounter and interact with us. In addition, based on advices from some students, putting them in the front seat helps get their involvement.

\subsection{Lessons Learned}

We obtain a variety of lessons learned from the primary school students with our learning-byplaying approach. Our lessons have two main parts.

The first part receives directly from the observation and interaction:

- Thai students are good quality of knowledge in basic OP but they lack skill in concluding what they learn as well as in explaining their ideas. To solve this problem, inspiration and confidence build-up are needed.

- Some students are aware of the safety in plugging in some electrical components to the AC supply and in using the laser pointer. This is valuable to us for the improvement of our electronic components in our Long Len kit.

- In addition to the enjoyment, interactions among students as well as curious questions from student show that they have creative thinking in learning things. For example, they use the color filter to learn the absorption of light without our advice.

- Process of learning approach should be flexible related to the interaction among students and us.

The second part gets from the evaluation form:

- High percent of assessment is achievable because we encounter the students with relaxing and playing. As a result, most students have fun while learning even though they thought OP seems difficult.

- Based on students' feedbacks collected after our activity, some students show an interest in studying OP in the future because they enjoy learning OP.

- From the open-minded outlook part, some students are planning to share their experiences gained during our activity to their family. 
Apart from having their hands-on our photonics kit, plain-text explanation and friendly conversation are necessary to get their cooperation.

\section{CONCLUSIONS}

With our learning-by-playing approach, most of primary school students in the grades 4-6 are capable of understanding advance optics and photonics. Our open-playing technique assists the students in opening their mind for learning. A significant point in this approach for Thai students is that instructors or teachers have to effectively organize students into the topics. Inspiring them is a first step in getting student attention. Then with proper demonstrations and communication skill, students are able to have critical thinking in some topics and show more interactions through the end of the class. From our assessment, we discover that most of participated students have fun during our class and gain more knowledge in OP. In addition, we have learned many lessons from the primary school students that will be taken into consideration to improve our activities. Further works include more effective ways to inspire students, to keep them learning OP, and to embed them with a critical-thinking process.

\section{ACKNOWLEDGMENTS}

Authors would like to thank NSTDA, SPIE, OSA and IEEE-LEOS for financial support. We are grateful to Miss Tiwaporn Polnpanich, an education officer in Payao, for her coordination with the schools in Payao. Mr. Srisombati Bhumkeaw, the director of DonModDang Wittakom School and his family, for their management of the schools in Ubolratchathani. Special thanks to all PTL members for their contribution to valuable discussions.

\section{REFERENCES}

[1] Michaels, S., Shouse, A. W., and Schweingruber, H. A., Ready, Set, Science!: Putting Research to Work in K-8 Science Classrooms, The National Academies Press, 2007.

[2] Semenova, I., "Teaching optics to primary school children," Proc. ETOP 2005, No. 094, pp. 362-363, Marseille, France, 24-27 October, (2005).

[3] Pompea, S. M. and Stepp, L., "Great idea for teaching optics," Proc. ETOP 1995, No. 168-1, pp. 168172, San Diego, California, USA, July 9-10, (1995).

[4] Guzik, R. P., "A tutorial on light and optics for grade school teachers," Optics \& Photonics News, Vol.15, No.6, pp.18-21, (2004).

[5] Varshneya, R. and DeGroote, J., "An encounter with optics for grade school students," Optics \& Photonics News, Vol.15, No.11, pp.16-17, (2004).

[6] Costa, Manuel F. M., Sporea, D., and Clementina, T., "Optics education in the frame of the Comenius "hand-on science" project," Proc. ETOP 2005, No.107, pp. 413-414, Marseille, France, 24-27 October, (2005).

[7] Magnani, N. and Donnelly, J., "Innovative methods to teach optics in the grade 5 classroom," Proc. ETOP 2007, pp. 151-159, Ottawa, Canada, June 3-5, (2007).

[8] Takayama, O., Niederberger, A., Ghenuche, P., Mathew, M., and Volpe, G., "El dia de la luz (the day of light) -two hours optics demonstration for secondary school students," Proc. ETOP 2007, pp. 160-165, Ottawa, Canada, June 3-5, (2007). 
[9] Lones, J. J., Maltseva, N. K., and Peterson, K. N., "Science and fun in a "magic show of light" from optical demonstrations on an overhead projector for elementary school student," Proc. ETOP 2007, pp. 429-434, Ottawa, Canada, June 3-5, (2007).

[10] Kruglak, H., "The compact disc as a diffraction grating," Physics Education, Vol.26, No.4, pp.255-256, (1991).

[11] Márquez, A., Álvarez, M. L. N., Méndez, D., and Beléndez, A., "Effective physical optics hands-on experience through the characterization of a CD and a DVD," Proc. ETOP 2005, No. 047, pp. 181-183, Marseille, France, 24-27 October, (2005).

[12] Mejías, P. M., Martínez-Herrero, R., Serna, J., and Piqueo, G., "Low-cost home experiments and demonstrations in optics," Proc. ETOP 2005, No. 016, pp. 60-61, Marseille, France, October 24-27, (2005).

[13] Pompea, S. M., Johnson, A., Arthurs, E., and Walker, C. E., "Hand-on optics: an educational initiative for exploring light and color in after-school programs, museums, and hand-on science centers," Proc. ETOP 2005, No. 064, pp. 276-278, Marseille, France, 24-27 October, (2005).

[14] Pompea, S. M. and Walker, C. E., "Design and evaluation of optics student competitions and cocontests for maximal educational value," Proc. ETOP 2005, No. 068, pp. 288-291, Marseille, France, 24-27 October, (2005).

[15] Dyomin, V. V. and Polovtsev, G., "Educational kit for optical experiments," Proc. ETOP 2007, pp. 310320, Ottawa, Canada, June 3-5, (2007).

[16] Hendon, S., Abdullah, S. and Salleh, K. M., "Light kit: from classroom practice to commercialization," Proc. the $1^{\text {st }}$ International Conference on Science Education in the Asia-Pacific, paper CL-B05, Bangkok, Thailand, November 28-29, (2007).

[17] Brecher, K., "Project LITE: Light Inquiry through experiments," Proc. ETOP 2007, pp. 166-174, Ottawa, Canada, June 3-5, (2007).

[18] Lones, J. J., Maltseva, N. K., and Peterson, K. N., "Science and fun in a "magic show of light" from optical demonstrations on an overhead projector for elementary school student," Proc. ETOP 2007, pp. 429-434, Ottawa, Canada, June 3-5, (2007).

[19] Jacobs, S. D., Gregg, L. L., Andrews, C. M., and Coppens, R. L., "Optics suitcase: educational outreach presentation guide," Posted online: http://www.opticsexcellence.org, Accessed on December (2008).

[20] Phoojaruenchanachai, S. and Chaitavon, K., "An educational kit for studying reflection and refraction light," Proc. the $27^{\text {th }}$ Congress on Science and Technology of Thailand, pp.780, Songkla, Thailand, October 16-18, (2001). (Thai language)

[21] Ministry of Education, Basic Educational Core Curriculum, (2008). (Thai language)

[22] http://www.ipst.ac.th/sci_curriculum, Accessed on October 2, (2008). (Thai language)

[23] Phoojaruenchanachai, $\bar{S}$. and Sumriddetchkajorn, S., "Long Len photonics kit," Proc. the $18^{\text {th }}$ Congress on Science and Mathematic Education in School, pp.94, Nakhon Pathom, Thailand, March 26-28, (2008). (Thai language)

[24] http://inquiry.illinois.edu/inquiry/definition.php, Accessed on February, (2008).

[25] Phoojaruenchanachai, S. and Sumriddetchkajorn, S., Long Len with Light, NanmeeBooks, (2009). (Thai language in publication processing)

[26] Lidar, M., Lundqvist, E., and Östman, L., "Teaching and learning in the science classroom: the interplay between teachers' epistemology," Wiley InterScience, pp.148-163, November 15, (2005).

[27] Sumriddetchkajorn, S. and Phoojaruenchanachai, S., "Shining-Spectrum-to-Society Project: A project for diffusing photonics education in Thailand," Proc. the $3^{\text {rd }}$ National Conference on Optics and Application, pp. 5-9, Bangkok, Thailand, August 15, (2008). (Invited paper)

[28] Sumriddetchkajorn, S., Photonics... the miracle of light, NanmeeBooks, February 2006. (Thai language)

[29] http://www.exploratorium.edu/snacks/bridge_light/index.html, Accessed on October 27, (2006).

[30] http://www.hands-on-optics.org/home, Accessed on January, (2007).

[31] http://www.gammaco.com/gammaco/product_list.php?id=PHYSICS, Accessed on June 13, (2008).

[32] http://www.arborsci.com/CoolStuff/Archives.htm, Accessed on April 4, (2006). 